\title{
Trešās paaudzes Universitātes sistēmdinamikas modeḷa izstrāde RTU vajadzībām
}

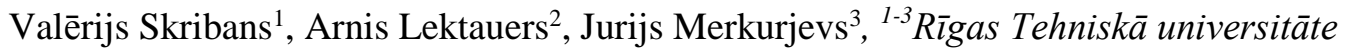

\begin{abstract}
Kopsavilkums. Inovatīvais 21. gadsimts izvirza jaunas prasības universitātēm: tās ir ne vien izglītības iestādes, bet arī pētniecības un inovāciju ieviešanas centri. Jaunās funkcijas universitātēm liek veikt būtiskas izmaiṇas savās vadības sistēmās. Pētījuma novitātes elements ir saistīts ar 3. paaudzes universitātes koncepcijas realizēšanu augstskolas modelī. Raksta mērḳis ir izstrādāt 3. paaudzes universitātes stratēgeiskās plānošanas sistēmdinamikas modeli. Pētījuma rezultāti ir pārbaudīti un ieviesti RTU. Ir secināts, ka universitātes attīstība ir atkarīga no spējām attīstīt inovatīvas tehnolog̣ijas, un mazo valstu augstskolām pastāv izaugsmes robežas.
\end{abstract}

Atslēgas vārdi: sistēmdinamika, augstākā izglītība, resursu vadība, finansējums, kvalitāte, inovācijas.

\section{IEVADS}

Universitāšu darbības plānošana ir aktuāla jebkurā valstī. Problēmas aktualitāti nosaka gan pieaugošais speciālistu pieprasījums, gan universitāšu pieejamo resursu ierobežojumi. N̦emot vērā iepriekšminēto, inovatīvais 21 . gadsimts universitātēm izvirza jaunas prasības: tās vairs nav tikai augstākās izglîtīibas iestādes, bet ir pētniecisko institūtu un inovāciju pārneses centru kopums. Tradicionālajā, pirmās paaudzes universitātē, universitātes loma ir saistīta ar speciālistu sagatavošanu. Otrajā paaudzē š̄ loma ir papildināta ar pētnieciskiem uzdevumiem. Trešajā paaudzē universitāte tiek definēta kā inovāciju izveides un pārneses centrs, saglabājot tradicionālos uzdevumus. Papildinot universitātes struktūru ar jaunām funkcijām, mainās universitātes plānošanas sistēma. Minētie apstākḷi nosaka piedāvātā modeḷa nepieciešamību un raksta aktualitāti.

Rakstā izpētîtā problēma ir saistīta ar stratēǵijas plānošanas sistēmdinamikas modeḷa izstrādi trešās paaudzes universitātei.

Novitātes galvenais elements ir saistîts ar trešās paaudzes universitātes koncepcijas realizēšanu universitātes modelī.

Pētîjuma objekts ir universitātes vadība un stratēóijas izstrāde universitātē. Pētījuma subjekts ir izmainas pēc trešās paaudzes universitātes koncepcijas realizācijas.

Raksta mērḳis ir izstrādāt trešās paaudzes universitātes stratēǵiskās plānošanas sistēmdinamikas modeḷa prototipu.

Lai sasniegtu mērkii, ir izvirzîti šādi uzdevumi:

- Izpētīi zinātnisko literatūru un universitāšu vadības modeḷus, balstoties uz šiem pētījumiem, izdarīt secinājumus par esošo modelı noderīgumu trešās paaudzes universitātes modelim.

- Izstrādāt trešās paaudzes universitātes stratēǵiskās plānošanas sistēmdinamikas modela prototipu.

- Atspoguḷot un novērtēt izstrādātā modeḷa vispārējo shēmu.
- Atspoguḷot un novērtēt modeḷa galvenos blokus, kā arī galvenos krātuvju - plūsmu shēmas blokus.

- Novērtēt modeḷa darbību, ka arī dažādas situācijas attīstības variantus.

Pētîjuma veikšanai ir izmantotas gan tradicionālās metodes laika rindu tendenču un regresijas metodes, gan specifiska imitācijas modelēšanas pieeja - sistēmdinamikas metode.

Pētîjuma metodologiskā bāze pamatojas uz sistēmdinamikas vadošo zinātnieku darbiem izglîtības jomā: M. Kenedijs, F. Barnabe, M. Vahdatzads, B. Oyo, Y. Barlass, M. Mahmouds, J. Hermanns.

Pētījuma rezultāti ir aprobēti un pielietoti Rīgas Tehniskajā universitātē (RTU).

\section{LITERATŪRAS ANALĪZE}

Analizējot sistēmdinamikas (SD) metodes pielietošanu augstākās izglītības jomā, ir jāpiemin šādi SD sabiedrībā labi paz̄̄stami pētnieki: Maikls Kennedijs, Federiko Barnabe, Mohammads Vahdatzads, Benedikts Oyo, Yamans Barlass, Mohameds Mahmouds, Džons Hermanns. N̦emot vērā, ka šiem autoriem ir pieredze izglītības modeḷu veidošanā, kas ir atspoguḷota atbilstošās publikācijās, tad, pamatojoties uz šo pieredzi, kā arī, ievērojot RTU apstākḷus un nosacījumus, ir izstrādāts jauns modelis.

Literatūras apskata pirmais uzdevums ir novērtēt SD metodes atbilstību un piemērotību universitāšu imitācijas modelıa izstrādei.

Autoru viedokḷu analīze, novērtējot SD metodes pielietojumu augstākās izglìitỉbas jomā, atspoguḷo gan pētāmās problēmas sarežğîtību, gan analizējamās metodes pamatuzdevumu novērtēt saišu un mijiedarbības daudzveidību pētāmajā objektā. Uz šì pamata var izdarīt atbilstošus secinājumus un veikt konkrētas metodes izvēli.

Analizējot iepriekš izstrādātos modeḷus un pieejamos literatūras avotus, raksta autori ir secinājuši, ka lielākā daḷa modeḷu ir saistīti ar ierobežotu līdzekḷu (finanšu, personāla utt.) sadales problēmu un/vai ar to izmatošanas efektivitāti (vai izglîtības kvalitāti). Katram no autoriem ir savs viedoklis par šīm problēmām un veidiem, kā šīs problēmas iespējams risināt.

Piemēram, M. Vahdatzads un M. Mojtahedzadehs [11] raksta par valsts un augstākās izglîtīibas sistēmas duālo lomu augstskolu attīstībā: universitâtei ir jābūt tiesīgai lemt par savu akadēmisko kursu un pētniecības darbību paplašināšanu, pamatojoties uz universitātes stratēgiskajiem plāniem, iespējām un ierobežojumiem. Tas nebūtu iespējams bez decentralizēta lēmumu pieņemšanas procesa valsts iestādēs (t.i., Zinātnes un izglītības ministrijā, budžeta un plānošanas organizācijās u.c.). Arī universitātei ir jādomā, kā nopelnīt naudu no privātajā 
sektora un nozarēm, tajos realizējot vairāk projektu un pētniecības darbu.

Benedikts Oyo piedāvā, papildus mācību maksai no studentiem, veidot ienākumus no iekšējām darb̄̄iām, piemēram, no īsajiem kursiem, konsultācijām un telpu īres [10].

Līdzīgs piedāvājums ir redzams arī iepriekšējos pētījumos, un ir labi paz̄istams kā ,citi ienākumi”. Tas ir termins, ko izmanto, apzīmējot ienākumus no tādām darbībām kā konsultācijas, īstermiņa un ilgtermiņa kursi, augstskolu telpu un iekārtu noma, un jebkura veida citi pakalpojumi, kurus var sniegt universitāte. Bet paralēla ienākumu plūsma var prasīt vairāk uzmanības ar to iegūšanu saistītajām izmaksām. Dažkārt resursi no universitātes pamatdarbības var tikt izmantoti papildus ienākumu plūsmas veidošanai. Daudzos gadījumos pieskaitāmo izmaksu problēma nav tik būtiska, ja universitāte ir spējīga ņemt saprātīgas pieskaitāmās izmaksas no komerciālajiem klientiem. Ir saprotams, ka iegūto līdzekḷu lielākā daḷa nonāks struktūrvienībā, kas rada ienākumus, vienlaicīgi pamatoti proporcionāli līdzekḷi tiks nosūtîti centram, lai papildinātu galvenās dotācijas punktus [8].

Atsevišķos gadījumos ir nepieciešams mainīt augstskolu finansēšanas sistēmu. Katru gadu universitāte plāno budžetu nākamajam finanšu gadam, un Zinātnes ministrija pieņem galīgo lēmumu par faktisko budžetu. Paredzamais budžets ir balstīts uz nākotnes vīziju, bet faktiskais budžets ir atkarīgs no iepriekšējā gada budžeta izpildes. Iespējamā problēma: lēmums par budžeta pienemšanu tiek piencemts dažādās organizācijās un politikas veidotāju starpā bez pietiekošas koordinācijas. Zinātnes un izglītîbas ministrijai ir jāmaina tradicionālo budžeta pieņemšanas veidu no dažu procentu iepriekšējā gada budžeta pārskatīšanas uz vajadzību, aktivitāšu un uz izaugsmi bāzētu budžeta pieņemšanu [11]. Interaktīvs dinamiskais simulācijas modelis var tikt paplašināts, iekḷaujot vairākus universitātes sistēmas aspektus, tādus kā budžeta veidošana, palīgpersonāls, un kopumā detalizētāk atspoguḷot tādus parametrus kā universitātes kapacitāte, infrastruktūra un projekti [1]. Katrs no universitātes aspektiem ir komplicēta apakšsistēma ar specifiskiem komponentiem, saitēm utt., piemēram, universitātes infrastruktūras kontekstā ir iespējams analizēt transporta, tai skaitā sabiedriskā transporta pieejamību un efektivitāti [13].

Visos gadījumos autoru analizētajos literatūras avotos ir vienots viedoklis, ka finansējuma problēmas var risināt trīs veidos: palielinot finansējuma apjomu, samazinot izmaksas un palielinot resursu izmantošanas efektivitāti. Lai risinātu minētās problēmas, tās jāpielieto kompleksi.

Ar finanšu problēmu risināšanu universitātēs vien nepietiek, nepieciešami pētījumi, modeḷi, kas vienlaikus var atspoguḷot gan kvantitatīvas, gan kvalitatīvas augstskolu pārvaldības problēmas [2]. Ar kvalitatīvo aspektu universitātēs parasti saprot izglītības un zinātniskā darba kvalitāti.

Piedāvātais modelis nodrošina universitāšu vadītājiem apmācības īstenošanas scenāriju plānošanas instrumentu. Piemēram, tas sniedz atbalstu kursu vadībai, fakultāšu darba slodzes analīzei, uz kā pamata tiek izstrādāti atbildības punkti, integrējot statistisko un finanšu kursu vadības informāciju. Modelis novērtē ilgtermiņa stratēgijas un politikas lēmumu efektu ietekmi, nodrošinot atgriezenisko saiti pirms lēmumu pieņemšanas. Visbeidzot, universitātei ir noteikti ieguvumi, izstrādājot iekšējās vides novērtēšanas sistēmu. Ieguvumi ir efektīva un centralizēta plānošana, decentralizēta lēmumu pieņemšana un resursu sadale fakultātēs, kā arī skaidra un savlaicīga informācija par rezultātiem [9].

Modeḷa prototips iekḷauj sevī vides vadības problēmas. Modelis risina grupu izmēru un fakultātes mācību slodzes problēmas uzṇemšanas brīdī: nosakot uzṇemšanas standartus, nosakot apmācības cenas un regulējot potenciālo studentu skaita pieaugumu. Modeli viegli pielāgot arī citu akadēmisko plānošanas jautājumu risināšanai [5].

Augstākās izglītības kvalitātes problēmu var risināt, efektīvi vadot universitātes darbību, ko savukārt var sasniegt, izmantojot modelēšanas instrumentāriju universitātes vadībā.

Nākošā augstākās izglītības iestāžu problēma ir saistîta ar zinātni un pētījumiem.

Zema pētījumu produktivitāte ir saistīta ar pētniecības finansējuma un pētniecības personāla nepietiekamību. Problēmu var risināt, nosakot minimālo publikāciju skaitu: minimālais publikāciju skaits ir nepieciešams pētniecības virziena studentiem (maǵistrantiem un doktorantiem) pirms studiju pabeigšanas. Fakultātes akadēmiskais personāls ar doktora grādu kopā ar pētniecības studentiem veido pētniecības grupas. Savukārt katra pētniecības grupa realizē vismaz vienu pētniecības projektu noteiktā laika periodā, un maksimālajam pētniecības grupu skaitam fakultātē ir jābūt ierobežotam [10]. Galvenais uzdevums ir pieņemt darbā vairāk personāla ar pamatdarbību pētniecībā. Maǵistra un doktora studijām ir liela ietekme uz pētniecības darbību un liels potenciāls, nodrošinot universitāšu ieguldījumu jauno tehnologiju un zinātnes attīstībā. Pētniecības rezultativitātes palielināšana ir iekšèjā mārketinga sadarbība ar fakultāti, kā arī klientu (kuram vienmēr ir taisnība) [11].

Gan kvalitatīvās, gan kvantitatīvās problēmas universitātēm tiek piedāvāts risināt, izmantojot universitātes vadības modelēšanu. Viena no piemērotākajām universitāšu modelēšanas metodēm ir sistēmdinamikas metode.

\section{PĒTİJUMA METOdoloG̣iJA}

Balstoties uz literatūras apskatu un iepriekš izstrādāto modeḷu analīzi, pētniecības grupa (autori) ir pieņēmuši lēmumu, pielāgot minētos modeḷus Rīgas Tehniskās universitātes vajadzībām. Šì ceḷa pirmā problēma ir tāda, ka autoriem nav pieejama pilna informācija par iepriekš izstrādātiem trešās paaudzes augstskolu modeḷiem. Jauna pieeja prasa jaunu modeli un jaunu metodiku. Šì raksta daḷa apskata inovatīvu pieeju, izstrādājot trešās paaudzes (3G) universitātes modeli Rīgas Tehniskajai universitātei, kā arī atspoguḷo efektīvākos un piemērotākos blokus no iepriekš izstrādātajiem modeḷiem, kas ir noderīgi arī trešās paaudzes universitātes modelim. 


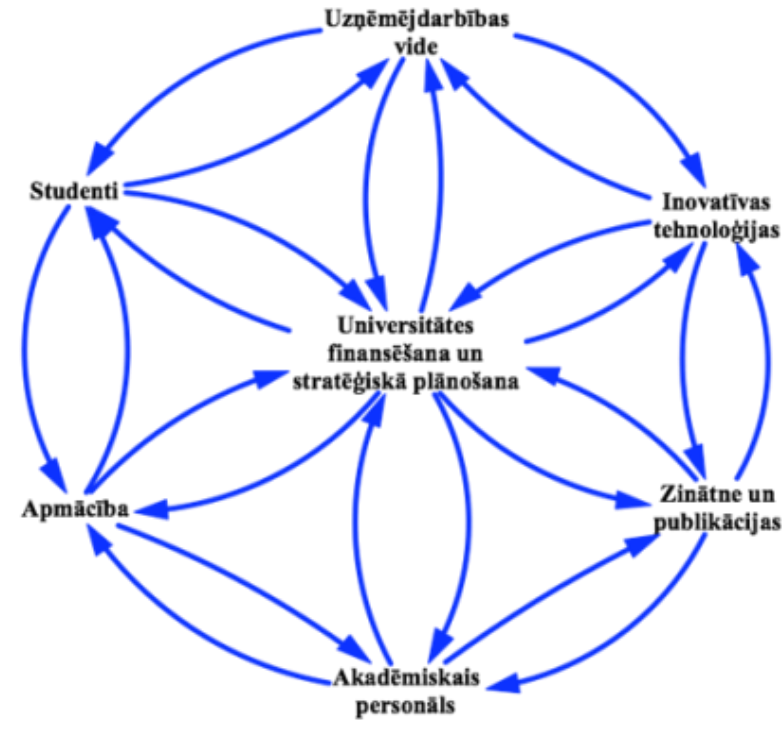

1. att. Modeḷa vispārējā struktūra.
Izstrādātā modeḷa vispārējā struktūra ir atspoguḷota 1. attēlā. Trešās paaudzes universitātes modeḷa vispārējā struktūra atspoguḷo galvenos universitātes dalībniekus (studenti, akadēmiskais personāls), aktivitātes (apmācība, zinātne), to savstarpējās saites, kopējo finansēšanu un stratēǵisko plānošanu. Konceptuālā modeḷa pamatā ir ideja par trešās paaudzes, jeb 3G universitātes ieviešanu, ko par mērķi ir atzinusi Rīgas Tehniskā universitāte, balstoties uz dažādu partneru interešu un lomu integrēšanu universitātes darbībā.

Trešās paaudzes pieejas pamatā ir universitātes veidošana ne tikai par izglītības iestādi, bet arī par inovatīvu tehnoloğiju pārneses centru, kurš sevī apvieno apmācību (izglītības procesus), pētniecību un inovāciju ievešanu.

Praktiski realizējot trešās paaudzes koncepciju, izstrādātajā modelī (1. attēls) katram modeḷa sektoram ir noteikta ietekme uz pārējiem modeḷa elementiem, bet centrālā loma ar vislielāko ietekmi modelī ir universitātes finansēšanas un plānošanas blokam, kas nosaka universitātes nozaru un struktūrvienību attīstības virzienus ilgtermiņā.

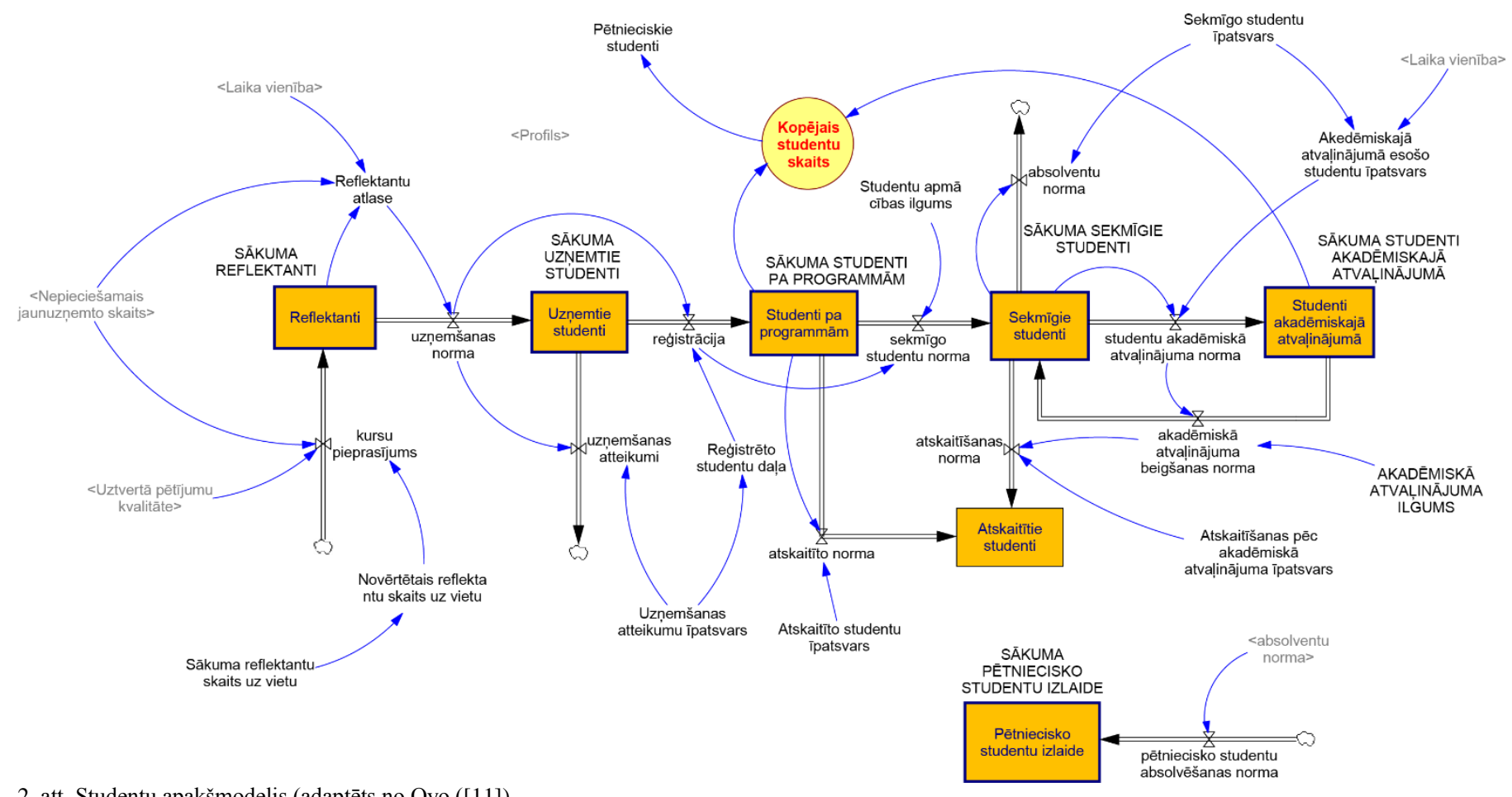

2. att. Studentu apakšmodelis (adaptēts no Oyo ([11]).

Vitāla loma modelī ir universitātes saiknei ar uzṇēmējdarbības vidi, pētniecības un attīstības (R\&D) sektoru, inovatīvu tehnologiiju izstrādi, ārēja finansējuma piesaistes nodrošinājumu. Universitātē radīto inovatīivo tehnologiju izmantošana ir būtisks universitātes darbības mērkis. Uzṇēmējdarbības veicināšana un atbalsts ir svarīga 3G universitātes funkcija papildus tradicionālajām pētniecības un izglītošanas funkcijām. Jaunrade un radošums ir tikpat svarīgs attīstības virzītājspēks un instruments kā racionālas pētniecības metodes.

Imitācijas modeḷa prototips ir izstrādāts, izmantojot sistēmdinamikas pieeju, kas kā efektīvs kvantitatīvas modelēšanas, analīzes un plānošanas līdzeklis pēdējā laikā arvien vairāk tiek izmantots augstākās izglītības pārvaldības praksē. Modeḷa praktiskā realizācija ir veikta sistēmdinamikas modelēšanas programmatūras Vensim vidē. Ar nelieliem uzlabojumiem (adaptāciju) modeli iespējams pielietot valsts iestāžu, lielmēroga uzņēmumu (korporāciju) darbības plānošanai, kā arī teritoriālajā plānošanā.

\section{TREŠĀS PAAUDZES UNIVERSITĀTES MODEḶA KOMPONENTI}

Ievērojot, ka izstrādātais modelis ir sarežḡìts, ar komplicētu struktūru un elementu savstarpējo sasaisti, rakstā tiek atspoguḷoti tikai tā nozīmīgākie elementi. 
Pirmais apskatāmais apakšmodelis ir studentu apakšmodelis (2. attēls). Šis apakšmodelis iepriekš jau ir sastopams literatūrā, un ir adaptēts no Oyo [11].

Studentu apakšmodelī ir izveidota sistēmdinamikas plūsma no reflektantu, uzṇemšanas, sadalījuma pa studiju programmām, analizējot sekmes un akadēmisko atvalinājumu izmantošanu līdz absolvēšanai un tālākai piesaistei zinātniskajam un akadēmiskajam darbam.

Apmācības apakšmodelis analizē studentu un personāla skaita attiecības, to ietekmi uz realizējamo kursu skaitu, personāla slodzi un apmācības kvalitāti. No vienas puses, 3G universitāte nodrošina augstākās izglītības pakalpojumus plašām cilvēku masām, tajā pašā laikā tā fokusējas uz izcilību, nodrošinot īpašas iespējas attīstīties un izpausties talantīgākajiem studentiem un akadēmiskajam personālam.
Akadēmiskā personāla apakšbloks modelē personāla skaita samazināšanos saistībā ar novecošanu, doktoru jaunās paaudzes sagatavošanu, personāla apmācību, pieredzes uzkrāšanu un kvalitātes celšanu. Lai nodrošinātu savu darbību, universitātē tiek piesaistīti dažādu jomu mācībspēki, zinātniskais personāls un studenti.

Zinātnes apakšmodelis analizē pētniecisko projektu skaitu, to radīto efektu un efektivitāti, projektu rezultātā publicēto publikāciju skaitu, universitātes zinātnisko kapacitāti, studentu iesaisti zinātnisko publikāciju sagatavošanā, to ietekmi uz noslēguma darbu un studiju kvalitāti. Izstrādātajā modelī pētniecības aktivitātes pēc sava rakstura ir definētas kā starpdisciplināras, atbilstoši vispārējai nostādnei par 3G universitāti.

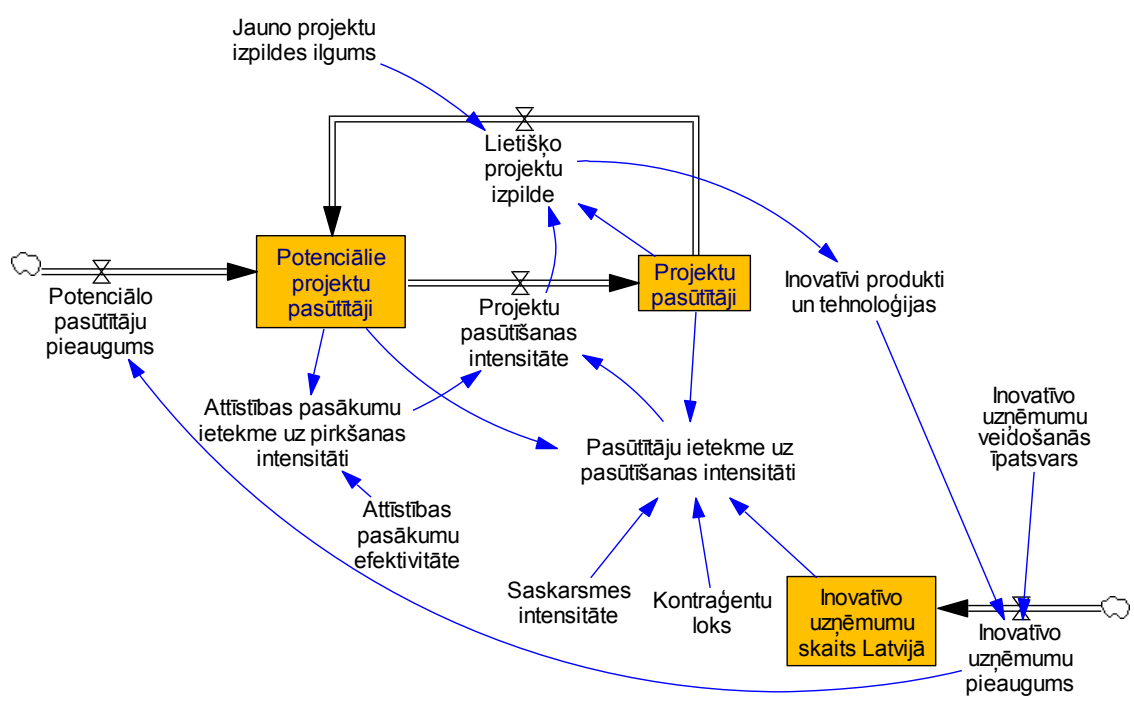

3. att. Universitātes modeḷa inovāciju apakšmodelis.

Kā jau teikts iepriekš, būtiska loma zinātnes saiknei ar uzṇēmējdarbību ir inovatīvu tehnolog̣iju attīstīšanai. Šim nolūkam modelī ir izstrādāts inovāciju radīšanas un izplatīšanas bloks (3. attēls), kā arī ir izpētīta tā ietekme uz universitātes darbību un ārējo vidi (uzṇēmējdarbības attīstību). Inovāciju bloks ir realizēts, balstoties uz klasisko Basa difūzijas modeli [4]. Balstoties uz Basa modeli, pētījumu autori ir izveidojuši inovāciju radīšanas un izplatîšanas apakšmodeli. Tas ir svarīgākais uzlabojums, galvenā $3 \mathrm{G}$ universitātes modeḷa sastāvdaḷa. Apakšmodelī $3 \mathrm{G}$ universitātes veiktās darbības maina inovatīvo uzṇēmumu skaitu valstī (Latvijā). Pieaugot inovatīvo uzñēmumu skaitam, pieaug potenciālais pētījumu pasūtītāju un inovatīvo klientu skaits. Ar laiku palielinās arī veikto pētījumu un izstrādāto inovatīvo produktu skaits. Tas ietekmē visus citus model̦a apakšmodeḷus: universitātes finansēšana palielinās; akadēmiskā personāla un studentu ieinteresētība universitātē arī palielinās. Inovatīvi produkti un tehnologiijas ir universitāšu konkurētspējas pamats 21. gadsimtā.
Universitātēm ir jāizstrādā, jāuzkrāj, jāīsteno un jāgūst labums no inovatīviem produktiem un tehnologijāàm.

Finansēšanas un stratēǵiskās plānošanas apakšmodelis modelē universitātes finanšu plūsmas: ieņēmumus un izdevumus mācību procesam, pētniecībai; apmācības cenas un izmaksas; novērtē universitātes kapacitāti, investīciju nepieciešamību attīstībai. Šis sektors ir saistīts ar visiem pārējiem modeḷa blokiem, jo universitātes finansēšana un stratēgiskā plānošana nosaka augstākās izglīīibas iestādes pastāvēšanas iespējas. Universitātei ir jādiversificē ieņēmumu avoti, finansējums jāpiesaista caur valsts nozīmes pētniecības centriem, kompetences centriem u.c.

N̦emot vērā modeḷa relatīivo sarežğîtību un ieejas datu daudzveidību, dažādām lietotāju un lēmumu pieṇēmēju grupām var interesēt dažādi modelēšanas scenāriji. Šim nolūkam modelī ir izveidota interaktīva modeḷa lietotāja saskarne (4. attēls). 


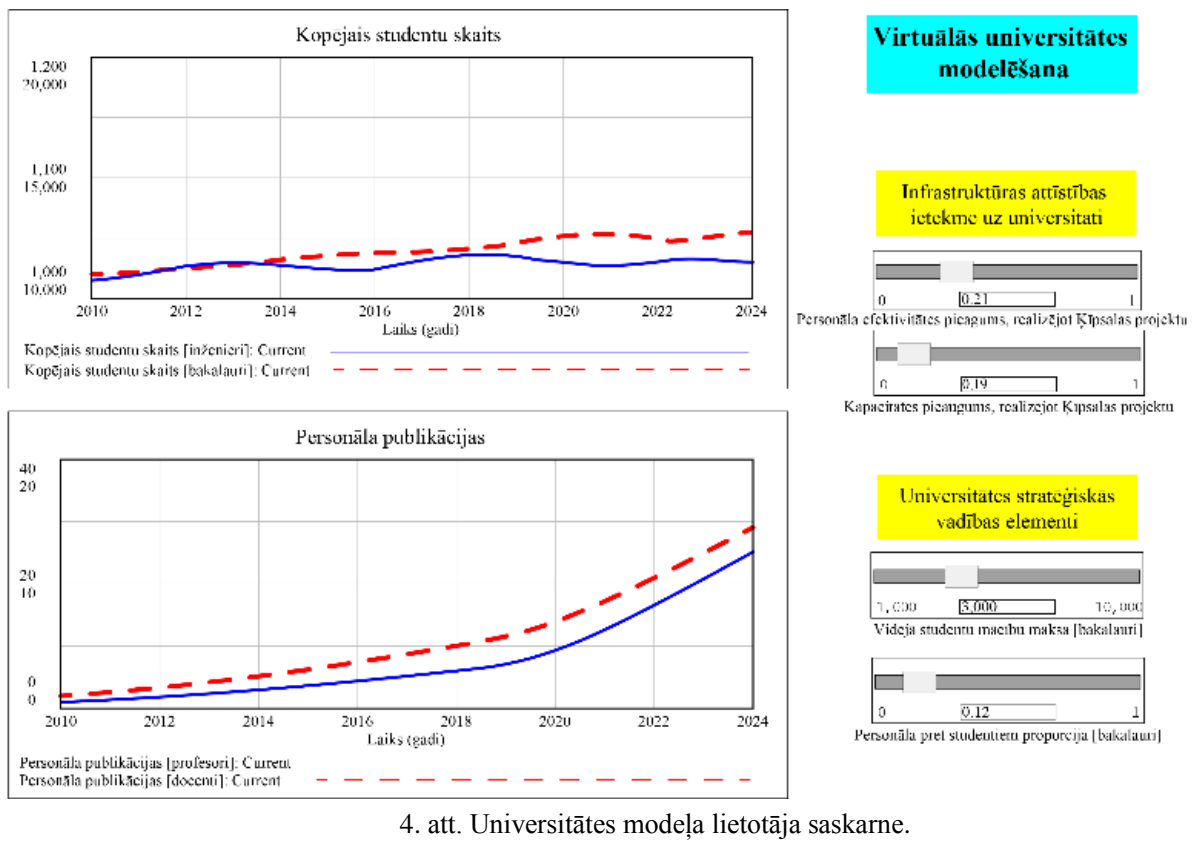

Interaktīva modeḷa lietotāja saskarne sniedz iespējas veikt interaktīvus sistēmdinamikas modelēšanas eksperimentus, mainot tādus parametrus kā ,zinātniskā personāla efektivitātes pieaugums" (realizējot attīstības projektus), „universitātes kapacitātes pieaugums" (realizējot attīstības projektus), „studiju maksa”, „studējošo un akadēmiskā personāla attiecība” un vairāki citi. Rezultātā pārskatāmā veidā tiek iegūta informācija par studentu kopējo skaitu, personāla publikācijām utt. Tādējādi, izstrādātais modelis ir izmantojams tiešā veidā, plānojot universitātes, izglītības un zinātnes sistēmas iestādes darbību valsts un uzņēmējdarbības līmeņos.

\section{MOdEL̨A REZULTĀTI}

Izstrādātais modelis kompleksi analizē universitātes procesus. Rakstā ir atspoguḷoti tikai būtiskākie ierobežojošo lielumu simulācijas rezultāti: modelētais studentu skaits un inovatīivu produktu un tehnoloǵiju dinamika.

5. attēlā ir atspoguḷoti modelēšanas rezultāti par kopējo studentu skaitu Rīgas Tehniskajā universitātē, kas iegūti, veicot eksperimentus ar izstrādāto sistēmdinamikas modeli, kur studentu apakšmodeḷa struktūra ir atspoguḷota 2. attēlā

Kopējais studentu skaits

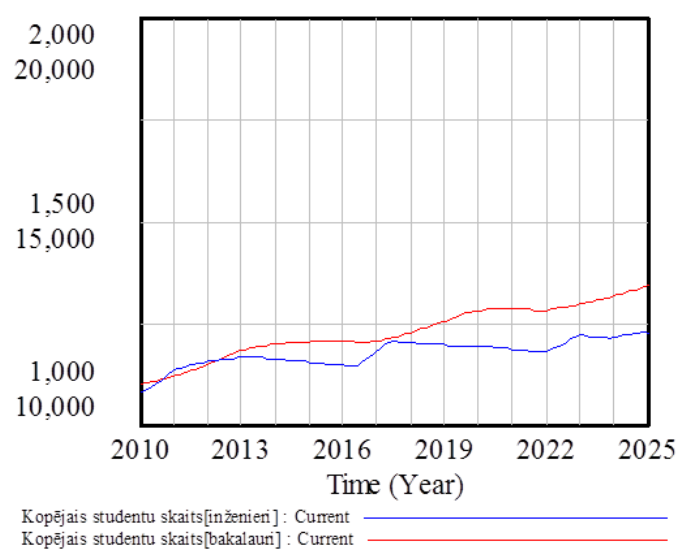

5. att. Prognozējamā studentu kopējā skaita dinamika.
Var prognozēt, ka ar pietiekamu finansējumu un efektīvu mācīšanas pieeju kopējais studentu skaits pieaugs, galvenokārt profesionāli orientētās studiju programmās.

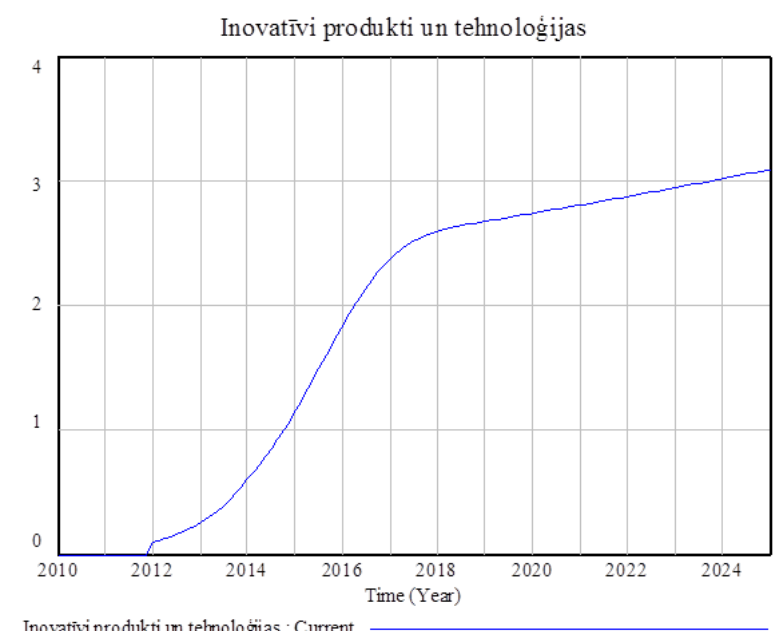

6.att. Inovatīvu produktu un tehnologiju dinamika 2012.-2025. gadu modelēšanas laika horizontā.

5. attēls rāda, ka Rīgas Tehniskajai universitātei pastāv izaugsmes ierobežojumi, lai tā attīstītos kā tradicionālā universitāte. Apstākḷos, kad iedz̄ivotāju skaits valstī (Latvija) samazinās, studentu skaita pieaugums 10-20\% ir vērtējams kā l̦oti optimistisks scenārijs. Šajos apstākḷos viens no universitātes veiksmīgas attīstības celiem ir izstrādāt inovatīivus produktus un tehnoloǵijas (un gūt labumu no tiem).

6. attēls atspoguḷo modelēto inovatīvo produktu un tehnologiju dinamiku laika periodā līdz 2025. gadam. Šis attēls rāda, ka, pareizi un sistemātiski îstenojot trešās paaudzes universitātes koncepciju, tuvākajā nākotnē gaidāms Rīgas Tehniskajā universitātē izstrādāto inovatīvo tehnologijiju skaita pieaugums. Ir redzams, ka pagaidām universitātē izstrādāto inovatīvo produktu skaits ir tuvs nullei. Nelielai universitātei 
5-15 inovatīvo tehnologiiju īstenošana varētu pozitīvā virzienā būtiski mainīt universitātes struktūru.

Piedāvātā modeḷa risinājums un rezultāti ir pamatoti un saskaṇoti ar esošās situācijas un stratēgiskās plānošanas datiem, kas iegūti no Rīgas Tehniskās universitātes vadības personāla.

\section{SECINĀJUMI}

Trešās paaudzes universitātes model̦a izstrādāšana ir aktuāla, ne tikai Rīgas Tehniskās universitātes, bet visas pasaules mērogā. Šobrīd pasaulē nav pilnībā pabeigtas, vienotas koncepcijas par trešās paaudzes universitāšu lomu un struktūru, līdz ar ko iepriekš nav izstrādāts šāda veida universitātes modelis. Š̀ raksta galvenā vērtība ir trešās paaudzes universitātes modeḷa vispārējās shēmas izstrāde, kā arī to sastāvdalu definēšana. Autori cer, ka pasaules vadošo universitāšu lielākā dạ̣a īstenos trešās paaudzes universitātes attīstības koncepciju, pamatojoties uz izstrādāto shēmu.

Analizējot model̦a rezultātus, ir secināts, ka noteiktos apstāklı universitātes attīstība ir atkarīga no spējām attīstīt un pārvaldīit inovatīvās tehnologíjas. Mazo valstu augstskolām pastāv izaugsmes robežas. Iespējams, pēc trešās paaudzes universitātes koncepcijas ieviešanas pasaulē, augstskolas sadalīsies augstākās izglītības iestādēs (vai mazās, vietējās, reǵionālās augstskolās) un trešās paaudzes universitātēs (ar pētniecības un inovāciju pārneses centriem). Šajos apstākḷos RTU uzdevums ir kā vadošai universitātei Latvijā attīstīties starptautiskā līmenī, iegūt vietu starp 100 labākajām universitātēm pasaulē, veicot inovatīvo tehnoloğiju izstrādi pēc universitātes pasūtījuma.

\section{LITERATŪRA}

[1] Barlas, Y., and Diker, V. G. Decision support for strategic university management: a dynamic interactive game. In Proceedings of the 14th System Dynamics Conference, Cambridge, Massachusetts, USA: System Dynamics Society, 1996.

[2] Barlas, Y., \& Diker, V. G. A dynamic simulation game for strategic university management (UNIGAME). Available from http://pdf.aminer.org/000/566/639/an_interactive_dynamic_simulation_ model_of_a_university_management_system.pdf [Accessed 8th February, 2012]

[3] Barnabè, F. From Ivory Towers to Learning Organizations: the Role of System Dynamics in the "Managerialization" of Academic Institutions. In Proceedings of the 22 System Dynamics International Conference, Oxford, England, 2004, pp. 40-59.

[4] Bass, F. M. A new product growth model for consumer durables. Management Science, Vol. 15, No. 5: Informs, 1969, pp. 215-227.

[5] Hermann, J. F., \& DeOlden, J. A Flight Simulator for University Department Planning. In Proceedings of the 14th System Dynamics Conference, 1996.

[6] Kennedy, M. A Pilot System Dynamics Model to Capture and Monitor Quality Issues in Higher Education Institutions Experiences Gained. In Proceedings of the 16th System Dynamics Conference, Quebec City, Canada, 1998, p. 7.

[7] Kennedy, M. Some Issues in System Dynamics Model Building to Support Quality Monitoring in Higher Education. In Proceedings of the 16th System Dynamics Conference, Quebec City, Canada, 1998.

[8] Kennedy, M., \& Clare, C. Some Issues in Building System Dynamics Model for Improving the Resource Management Process in Higher Education. In Proceedings of the 17th International System Dynamics Conference, Wellington, New Zealand, 1999.

[9] Mohamed, M., \& Peter Genta, P. Microworld of an Open University: A Strategic Management Learning Laboratory. In 1SDC, 1993, pp 318-327.

[10] Oyo, B., Williams, D., and Barendsen, E. A system dynamics tool for higher education funding and quality policy analysis. In Proceedings of the 26th International Conference of the System Dynamics Society, Athens, Greece: System Dynamics Society, 2008.

[11] Vahdatzad, M. A., \& Mojtahedzadeh, M. T. Some issues in the strategic management in a fast growing academic Institution: The case of University of Yazd. In 18th International Conference of the System Dynamics Society, 2000, pp. 6-10.

[12] Skribans, V. A Case Study of EU Economic Formation with System Dynamic Method. In Proceedings of The 17th World Multi-Conference on Systemics, Cybernetics and Informatics, USA, Orlando, International Institute of Informatics and Systemics, 2013, 60.-65.pp.

[13] Lektauers, A., Petuhova, J., Teilans, A., Kleins, A. Development of an Integrated Geosimulation Environment for Public Transit Analysis and Planning // Rīgas Tehniskās universitātes zinātniskie raksti. 5. sēr., Datorzinātne. Informācijas tehnologiija un vadības zinātne. - Rīga: RTU Izdevniecība, 2012. 200.-205. lpp.

[14] Merkuryev, Y. Modelling and Simulation of Complex Systems: Methodology and Practice. An Overview. Information Technology and Management Science. RTU, 2012, Vol. 15, p. 32-44.

[15] Krishans, Z., Mutule, A., Merkuryev, Y., Oleinikova, I. Dynamic Management of Sustainable Development. Methods for Large Technical Systems. Springer-Verlag, London, 2011. 163 p. http://dx.doi.org/10.1007/978-0-85729-062-5

Valerijs Skribans holds a PhD Degree in Economics (Dr.oec.), Riga Technical University, Latvia, 2006.

Leading researcher, Associate Professor of Riga Technical University; has experience of managing a department; more than fifteen years experience of practical work in economist and financial officer positions. Specialist in system dynamics.

Member of International System Dynamics Society, Society for the Study of Emerging Markets, Archive of the Munich Personal Research Papers in Economics, Russian System Dynamics Society, Imitation and Modelling Society (Latvia), Latvian Association of Econometrics. Author of more than 100 scientific publications, including 3 books.

Address: Kalnciema Str. 6 - 216, LV1007, Riga, Latvia

Telephone and e-mail address: +371 26429535, valerijs.skribans@rtu.lv

Arnis Lektauers is an Associate Professor at the Department of Modelling and Simulation of Riga Technical University, Latvia. He obtained the Dr.sc.ing degree in Information Technology in 2008 from Riga Technical University. His main professional interests include the development of interactive hybrid modelling and simulation algorithms with an application to complex systems analysis and the research of industrial, economic, ecological and sustainable development problems. A. Lektauers is the Secretary of Latvia section of the Institute of Electrical and Electronics Engineers (IEEE), a member of Latvian Simulation Society and System Dynamics Society; author of 1 textbook and more than 30 papers in scientific journals and conference proceedings in the field of Information Technology.

Address: Riga Technical University, 1 Kalku Str., LV-1658, Riga, Latvia E-mail address: arnis.lektauers@ @rtu.lv

Jurijs Merkurjevs is Professor, Head of the Department of Modelling and Simulation of Riga Technical University. He obtained the Dr.sc.ing. degree in System Identification in 1982, and Dr.habil.sc.ing. degree in Systems Simulation in 1997, both from Riga Technical University. His professional interests include modelling and simulation of complex systems, methodology of discrete-event simulation, supply chain simulation and management, as well as education in the areas of simulation and logistics management. Professor Merkuryev is a corresponding member of the Latvian Academy of Sciences, president of Latvian Simulation Society, board member of the Federation of European Simulation Societies (EUROSIM), senior member of the Society for Modelling and Simulation International (SCS), and Chartered Fellow of British Computer Society. He is an associate editor of Simulation: Transactions of The Society for Modelling and Simulation International and editorial board member of International Journal of Simulation and Process Modelling. He authored more than 300 scientific publications, including 7 books and 6 textbooks. Address: Riga Technical University, 1 Kalku Str., LV-1658, Riga, Latvia E-mail address: jurijs.merkurjevs@ rtu.lv 
Valerijs Skribans, Arnis Lektauers, Jurijs Merkurjevs. Third Generation University System Dynamics Model Development for RTU.

Topicality of the problem of university performance planning is determined by the growing demand for highly qualified specialists (as a basic product of traditional universities) and limited resources of universities such as financial, personnel and other resources. At the same time, the innovative century sets new requirements for the universities: now they are not only higher education institutions, but also research and innovation implementation centres. The notion of the third generation defines the university as an innovation generation, transfer and implementation centre, while maintaining the traditional university functions. The addition of new features to universities requires fundamental changes in university management systems.

Novelty of the research is connected with the implementation of the 3rd generation university concept within the university model. The object of research is university management and strategy development for university. The subject of research is university changes, after the implementation of the 3rd generation university concept.

The paper aims to develop the 3rd generation university strategic planning model. Research results are tested and implemented at Riga Technical University. Development of the 3rd generation university model is topical not only for RTU, but for the entire world. At this moment, in the world a fully completed, unified concept of the 3rd generation university has not been developed yet; accordingly, the 3rd generation university model has not been previously developed. The main contribution of this paper is development of the general scheme of the 3rd generation university model with its components.

Analysing practical implementation of the developed scheme and the developed model, it has been concluded that in some conditions, the development of universities depends on the ability to develop and manage innovative technologies. Universities in small countries have growth limits. It is probable that after the development of the 3rd generation university concept in the world, universities will divide again into high education institutions (or small, local, regional universities) and the 3rd generation universities (with research centres and innovation implementation centres). In these conditions RTU, being the leading university in Latvia, has set a task to get a rank in the top 100 universities in the world with regard to the level of development of innovative technologies for university needs.

Валерий Скрибан, Арнис Лектауерс, Юрий Меркурьев. Разработка модели университета третьего поколения для РТУ с использованием метода системной динамики.

Актуальность проблемы планирования работы университета подчеркивается растущим спросом на высококвалифицированных специалистов (как основной продукт традиционных университетов) и ограниченными ресурсами университетов. В то же время инновационное столетие выдвигает новые требования для университетов: теперь они являются не только вузами, но и центрами исследований и внедрения инноваций. Третье поколение определяет университет как центр инноваций, ответственный за разработку и внедрение новых технологий при сохранении традиционных функций университета. Новые требования к университетам требуют фундаментальные изменения в системах управления университетами.

Элемент новизны связан с реализацией концепции третьего поколения в модели университета. Объектом исследования является управление и стратегия развития университета. Предметом исследования являются изменения в модели университета, после внедрения концепции университета третьего поколения.

Цель исследования состоит в разработке модели стратегического планирования университета 3-го поколения. Результаты исследования опробованы и внедрены в Рижском техническом университете.

Разработка модели университета третьего поколения является актуальной не только для РТУ, но и для всего мира. На данный момент в мире не существует полностью завершенной, единой концепции университета третьего поколения, соответственно, ранее не была разработана модель университета третьего поколения. Главная ценность работы заключается в разработке общей схемы модели университета третьего поколения.

Анализируя практическое воплощение разработанной схемы и разработанную модель, можно сделать вывод, что в некоторых условиях развитие университетов зависит от способности развивать и внедрять инновационные технологии. Университеты малых стран имеют пределы роста. Возможно, после развития концепции университета третьего поколения в мире, университеты разделятся на высшие учебные заведения (или небольшие, местные, региональные университеты) и университеты третьего поколения (с исследовательскими центрами и центрами внедрения инноваций). В этих условиях РТУ поставил задачу войти в топ-100 университетов мира по развитию инновационных технологий для нужд университета. 